[0101

\title{
三層積層アルミ板における振動减衰特性
}

Vibration Damping Properties of Three Layered Aluminum which has Viscoelastic Material 正 遠藤 紘 (秋田高専)

○打川 淳 (秋田高専専攻科)

Hiroshi ENDO, Akita National College of Technology, 1-1, Iijima Bunkyocho, Akita-shi, Akita Jun UCHIKAWA, Akita National College of Technology Advanced Engineering Faculty

Key Words : Vibration Damping, Constrained Type, Loss Factor, Vibration Mode Three Layered Beam of Aluminum

1. 緒言

近年、自動車、鉄道車両、産業機械から家電、情報通 信機器などにいたるまで、多くの機械で高速化、軽量 化が重要視されてきている。

それらに伴って機械の振動、騒音を抑制することは、 環境問題としてだけでなく機器の機能向上や信頼性 を高めるために避けて通れない問題である。

振動や騒音を低減する方法は既に多くの方法が提案 され、実用的にも用いられている。しかし、これらの 方法の多くは重量の著しい増加や機能を損ねるなど 実用的に解決すべき多くの問題がある。

振動、騒音を抑制する方法として、構造部材に振動减 衰性能（制振性能）を付与させることは既によく用い られている。それらの中で 2 枚の銅板の間に粘弾性物 質を挟んだ 3 層積層鋼板は大きな振動减衰特性（損失 係数）が得られることは良く知られており、制振鋼板 として実用的に用いられている。しかし、3 層積層銅 板の損失係数は、材料の構成条件、各層の材料特性值 温度、周波数、さらに振動モードや波長によって大き く変化するとされている。

一方、アルミは密度が小さく軽量化の観点からは適す る材料であるが、ヤング率が低く曲げ剛性低いため振 動しやすいと考えられている。

そこで、本研究ではアルミ板を用いた 3 層積層板の振 動减衰特性について研究し、鋼板の場合とその効果を 比較検討し、アルミ板に対する最適な制振処理条件や その有効性および最適な使用条件を明らかにするこ とを目的とした。

\section{2. 研究方法}

損失係数の測定は、Fig. 1 に示すように試験片の 中央部をインピーダンスヘッドに固定し、インピーダ ンスヘッドを介して加振器で加振する中央支持一中 央加振法を用いた。このときの加振力 $\mathrm{F}$ と加速度 $\mathrm{A}$ 力 ら FFT によって伝達関数 $\mathrm{A} / \mathrm{F}$ の周波数応答を求め、 さらにそのリアルパートから損失係数 $\eta$ を求めた。 実験に用いた三層積層アルミ板は、アルミの板厚をそ れぞれ厚さ $6 \mathrm{~mm}$ と $0.5 \mathrm{~mm} 、 3 \mathrm{~mm}$ と $3 \mathrm{~mm} 、 6 \mathrm{~mm}$ と $3 \mathrm{~mm}$ の基 板と拘束板を用い、中間層の粘弾性材料は厚さ $1 \mathrm{~mm}$ 一定にしてはさみ三層積層アルミ板とした。この粘弾 性材料は常温での制振効果の大きいものを使用して 実験し、損失係数の周波数依存性およびモード次数依 存性を明らかにするため、試験片長さを $150 \mathrm{~mm}$ $400 \mathrm{~mm}$ まで変化させ、また温度依存性を見るために試 験片を恒温層に入れ、温度を $-20^{\circ} \mathrm{C}$ から $80^{\circ} \mathrm{C}$ まで変化 させて損失係数 $\eta$ を測定した。

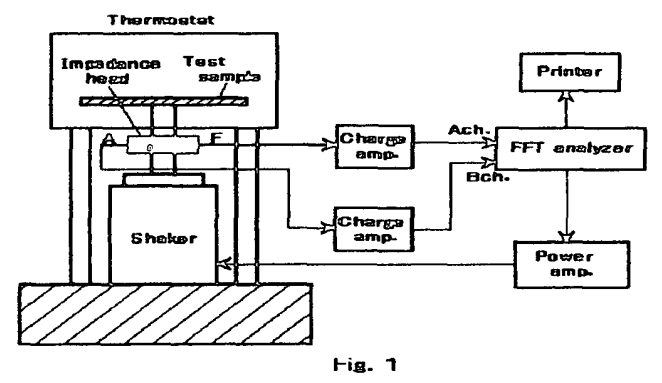

3. 実験結果

$3-1$ 温度依存性

Fig. 2,3 は基板厚さ $6 \mathrm{~mm}$ に拘束板 $0.5 \mathrm{~mm}$ を貼り付け

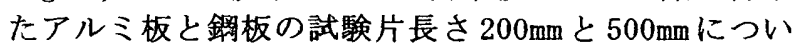
て測定した損失係数と温度の関係を示したものであ る。これらの図においては、モード次数ごとの損失係 数の温度依存性を示し、周波数の影響はここでは無視 している。これらの図から明らかなように、損失係数 はある温度でピークとなる温度によって大きく変化 する特性を有している。アルミ板と鎆板を比較すると 鋼板の各次モードのピーク温度がアルミに比べ低く、 ピークの值は短い試験片では 1 次モードが 2、3 次モ ードより高くなりモード次数によって大きく異なっ ているのに対し、長い方の試験片ではあまり変わらな い。つまり試験片が長くなるほど $2 ， 3$ 次モードの損 失係数のピーク值が高くなるという举動を示してい る。アルミ板の場合は試験片の長さに関わらず、 3 次

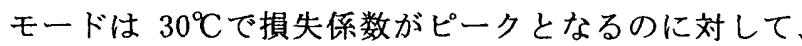

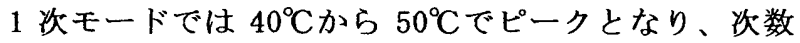
モードが高いほどピーク温度が低い傾向を示す。その 他の長さの試験片についてもこれらと同様な挙動を 示した。しかし、このような挙動は周波数の影響を受 けているわけであり、直ちにモード次数の影響や試験 片長さの影響とは言及できないところである。

\section{$3-2$ モード依存性}

Fig. 4, 5 はモード次数の影響を明らかにするために 温度ごとにモード次数をパラメーターとして損失係 数と周波数の関係を示した図である。堿衰効果が現れ ないー $20^{\circ} \mathrm{C}$ から $0^{\circ} \mathrm{C}$ の低温部では、損失係数に対する 次数モードの影響は見られない。それに対し $10^{\circ} \mathrm{Cに}$ なると次数モードの影響が現れ、1 次モードと $2 、 3$ 次モードとは同一周波数上でに対して異なる損失係 数を持ち、2、3 次モードの方が大きい值となってい る。損失係数がピークとなる $40^{\circ} \mathrm{C}$ から $50^{\circ} \mathrm{C}$ では 1 次 モードの損失倸数が大きくなり、1、2、3 次モードが 一つの曲線状になり、再びモード依存性が認められな くなる。 


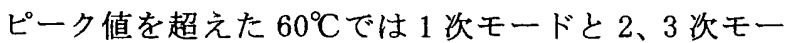
ドの損失係数は周波数に対して異なった值を示し、 $10^{\circ} \mathrm{C}$ 付近とは逆に 1 次モードの損失係数のレベルが 2 、 3 次モードより大きくなり再びモード依存性が見ら れる。 $80^{\circ} \mathrm{C}$ では $60^{\circ} \mathrm{C}$ と同様の傾向を示すが 1 次モー ドと $2 、 3$ 次モードとの損失係数の差が小さくなって いく。さらに温度が上がると低温部と同様に損失係数 のモード依存性は見られなくなる。アルミ板のモード 依存性の挙動としては鋼板と同様の傾向となってい た。異なる点はアルミ板の方がピーク温度が多少高く、 損失係数の值も多少大きくなった。

\section{$3-3$ 材料の構成条件の影響}

Fig. 6, 7 は材料の構成条件を変えた、1 次モードと 3 次モードの損失係数と温度の関係を示している。ど のモードでもアルミ板 $3-3 \mathrm{~mm}$ の損失係数が一番大 きく、次にアルミ板 6-3mm となり、次にアルミ板 6 $-0.5 \mathrm{~mm}$ 、鋼板 $5.7-0.4 \mathrm{~mm}$ となっている。アルミ 板 6-0.5mm と鎆板 5.7-0.4mm では多少アルミの 方が大きいが、ほぼ同じ挙動となっている。どの厚さ でも高次モードになるにつれて損失係数が小さくな っている。試験片が長くなると、どの厚さにおいても 1 次モードではピーク值はほとんど変わらないがピ 一ク温度が高くなっている。3 次モードでは試験片が 長くなるとピーク温度は変わらないが、ピーク值は高 くなっている。三層積層アルミ板では、基板と拘束板 が等厚の場合に最も振動减衰性能の効果が大きいこ とを示す。これは基板と拘束板の曲げ変形が粘弾性材 料層にせん断変形を生じさせているためであり、基板 と拘束板との曲げ剛性が大きく異なる場合では、基板 と拘束板の厚さの比が小さいほど振動減衰性能の効 果が大きくなる傾向が見られる。

\section{3-4 試験片長さ（波長）の影響}

Fig. 8 はアルミ板と銅板の試験片の長さとピーク值 の関係を示している。アルミ板は鋼板に比べ損失係 数のピークの値が多少大きく、試験片が短くても長 くても各モードによって損失係数のピーク值はそれ ほど大きな変化はなく、波長よる各モードのピーク 值への影響は見られない。鋼板の場合、1 次モードは 長さが変わっても損失係数のピーク值はあまり変わ らないが $2 、 3$ 次モードは長さに比例して損失係数の ピーク值も大きくなる。最終的にはどのモードもあ る值に収束する傾向となる。よって損失係数のピー ク值は 1 次モードでは長さにあまり依存しないが、2、 3 次モードは長さに大きく依存する。

\section{4. 結言}

本実験の結果から、アルミ板に粘弾性材料を介して 拘束として基板の $1 / 10$ 程度の拘束板を取り付けた三 層積層板も、銅板の三層積層板と同様に大きな損失 係数が得られる事が明らかになった。また、その損 失係数は温度、周波数、モードの影響を受けるが、温 度については極めて敏感であるのに対して周波数依 存性は小さい。損失係数はモード次数の影響を大きく 受け、同一周波数、同一温度でもモードによって異な った損失係数となる場合があり、特に 1 次モードと高 次モードでは異なった挙動を示す。また、三層積層ア ルミ板は鋼板に比べ材料に生じる波長の影響は小さ く、材料の構成条件において基板と拘束板の厚さの比
が小さいほど振動減衰性能の効果が大きくなる。アル ミの三層積層板は機械構造部材の重量の増加を抑え て効果的に制振処理が行える事が明らかになった。
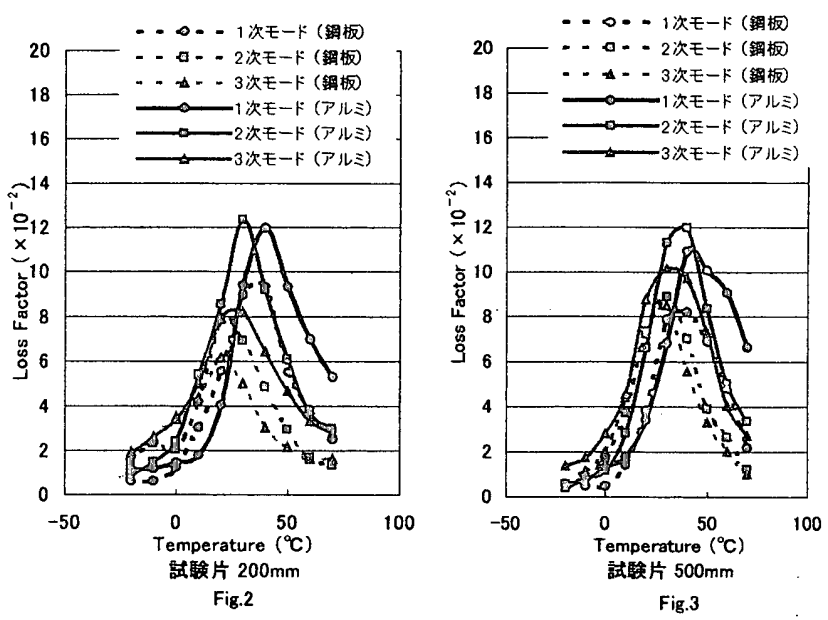

Fig.3

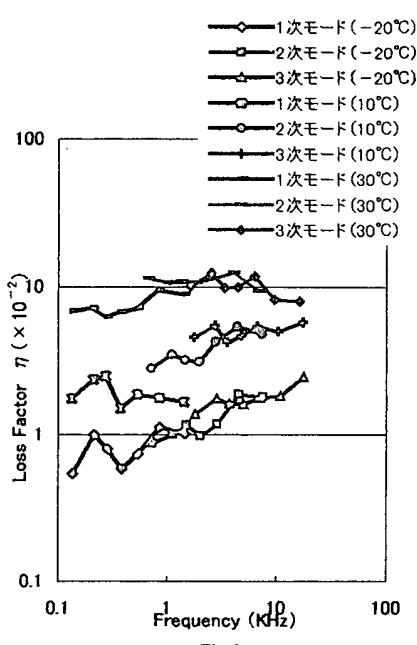

Fig. 4
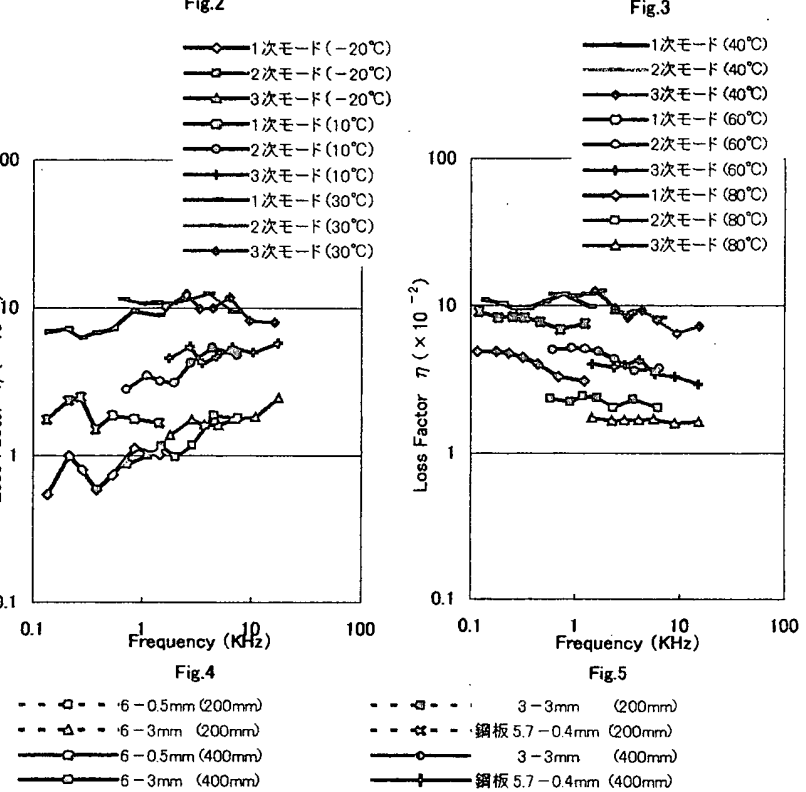

- $0.3-3 \mathrm{~mm} \quad(200 \mathrm{~mm})$

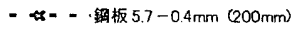
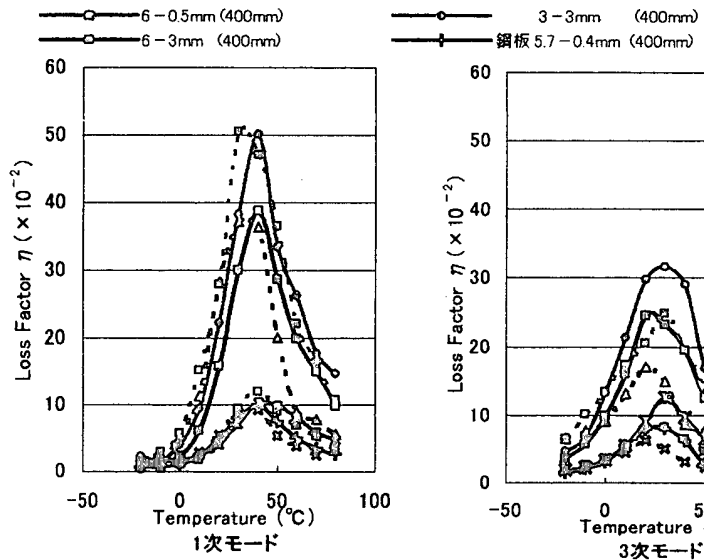

板 $5.7-0.4 \mathrm{~mm}(400 \mathrm{~mm})$

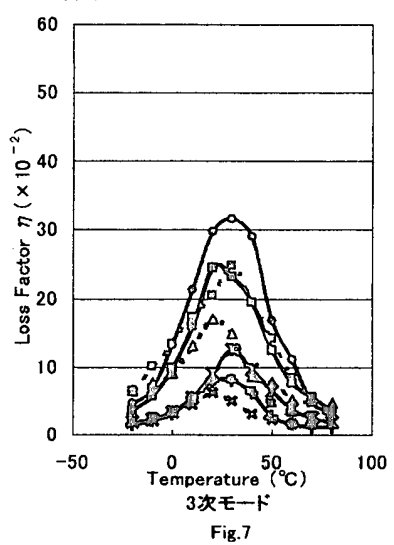

Fig.6

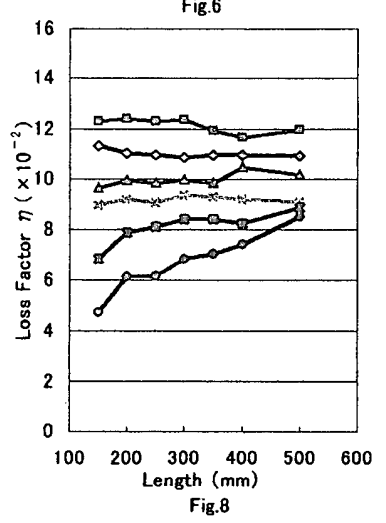

